Apidologie, 1981, $12(1)$, 57-67.

\title{
THE CONQUEST OF A BOMBUS TERRESTRIS COLONY BY A PSITHYRUS VESTALIS FEMALE
}

\author{
Cor VAN HONK (1), Peter-Frank RÖSELER (2), Hayo VELTHUIS and Marieke MALOTAUX \\ Laboratory of Comparative Physiology, State University Utrecht, the Netherlands
}

\begin{abstract}
SUMMARY
Two females of Psithyrus vestalis were caught when they were in search for nests of their host, and introduced in the outer compartments of the nestboxes of captive Bombus terrestris colonies. Their behaviour towards queen and workers of the host species was registered on videotape and analysed. The Psithyrus are able to prevent worker ovipositions for some time by displaying agonistic behaviour, but apparently do not produce pheromones inhibiting ovary development. Their reproductive success depends largely upon the age of the workers that survive their assaults. Workers that are three weeks old start to lay eggs, thus placing the Psithyrus in a position similar to that of the Bombus queen at the end of their dominance over the workers, when she loses her reproductivity.
\end{abstract}

\section{INTRODUCTION}

The Psithyrus (cuckoo bumble-bees) have puzzled generations of biologists. KIRBY (1802) noticed that they could be distinguished from other bumble-bees morphologically, the most striking difference being that Psithyrus $\left(P_{s}\right.$. ) lack the pollen collecting apparatus on their posterior tibia. The most important implication of this is that the females of $P s$. do not collect pollen to feed their offspring. Other early observers who found them in nests of Bombus (B.) concluded that both species lived together in some kind of symbiosis, the $P s$. feeding on the pollen collected by the hosts and rendering them some unknown service in return. According to HofFer (1889) however the Ps. female and her host did not live together as peacefully as it appeared at first, and their " relationship " was very much to the disadvantage of the host species. Observations made on nests of $B$. lapidarius and $B$. terrestris containing their parasites Ps.

(1) Supported by the Netherlands Organization for the Advancement of Pure Research, ZWO.

(2) Zoological Institute II, University of Würzburg, West-Germany 
rupestris and Ps. vestalis respectively led SLADEN (1912) to conclude that usually the Ps. kill the host queen, since in all the nests he dug up, the $P s$. female had replaced the host queen. He also conducted experiments and concluded that the Ps. locates the colony of the host species olfactorily. Furthermore he observed that the host queen was not killed instantly when the Ps. female entered but later. Due to the abundance of the colony's food supplies, the intruder's ovaries develop and she starts laying eggs : this behaviour ultimately leads to severe fights with the host queen, which the latter inevitably loses. The workers of $B$. who are living in a colony headed by a Ps. become fertile and start to lay eggs, but in the nestes studied by SLADEN no males hatched. This, in his opinion, is due to the oophagy of the Ps. female. In the case of the North American species the situation appears to be somewhat different. According to PLATH (1934), Ps. ashtoni and the queen of its host species, B. affinis, live together without obvious signs of animosity. Hoвbs (in MiChENER, 1974), in the species he observed, never found a colony in which a $P$ s. female had killed the $B$. queen. The North American $P$ s. females, on entering a colony, appear to be more conciliatory than those species studied by Sladen. Richards (in Michener, 1974), like HobBs, made his observaticns in Alberta on three species of $P s$. that do not show strict host specifity (in contrast to the species reported by SLADEN). While collecting bumble-bee nests in the Utrechtarea we twice found a $B$. pratorum colony containing a Ps. rupestris female. The $B$. colonies still had their own queen. We removed the $P$ s. females from the colonies because we were not interested in the phenomenon at that moment. The B. pratorum colonies prospered and did not show any sign of Ps. progeny. Having studied the aggressiveness of a Ps. citrinus female entering a B. bimaculatus colony, Plath (1934) concluded that $P s$. does not kill a host queen if she is smaller and weaker, but the does attack a queen larger than herself. BUTLER and FrEe (1959) reported that a PS. female adopts the strategy of a direct assault on the colony, making preliminary stinging movements towards workers by whom she is attacked severely.

In this paper, we report on observations made on two B. terrestris colonies into which we deliberately introduced a female $P$ s. vestalis. Special attention was paid to the behaviour that the Ps. female displayed towards the workers of the host species. This behaviour is compared to that of a $B$. terrestris queen towards her own workers. to find out to what extent the agonistic behaviour of a $B$. terrestris queen helps her to establish and maintain her dominant position in the uninfested colony.

\section{METHODS}

The colonies we used for this experiment were started with queens of $B$. terrestris which we caught in early March 1978 on Erica carnea c.v. in the garden of the old " Hoofddijk " fortress near Utrecht. The queens were placed in wooden boxes, and treated as described earlier (VAN HoNk et al., 1980). The emerging workers were marked with identifying numbers. Ps. vestalis females were collected at the end of May when they were hovering in the air about $10 \mathrm{~cm}$ above the vegetation of the 
embankment of the canal surrounding the fortress. They were introduced into the outer compartment of the nestboxes. On the first of June a Ps. female was introduced into a colony containing 40 workers; on the 5 th of June we introduced a Ps. female into another colony containing 27 workers. The whole process of introduction was recorded on videotape for closer analyses. In addition, observations were made directly at the nestbox at the moment of introduction.

\section{RESULTS}

Colony $N^{\circ}$. 6. This colony contained 40 workers when Ps. vestalis was introduced.

When the $P s$. was introduced there were no workers in the outer compartment, and the Ps. walked in the outer compartment for a few minutes before she was detected by one of the three workers who had entered the outer compartment. She was inspected by one worker whose antennae were moving very fast near the head of the intruder. The worker started to buzz but neither of the two initiated a fight. The other two workers started to walk very quickly through the outer compartment and met the Ps. several times. She was inspected several times and most of the inspections ended with a short or more prolonged buzz by the worker. No special behaviour was observed when the worker returned to the nest. Another worker in the outer compartment lifted her middle leg on meeting the $P$ s., rolled over onto her back and defecated. After a minute, the workers outside also started to buzz when they were not in the direct proximity of the intruder, and the buzzing became more frequent. Three minutes after the first encounter between the Ps. and a worker, one of the workers made stinging movements towards the $P s$., holding her in a tight grip.

The Ps. got rid of the worker easily and started walking through the box again. When she arrived at the honey reservoir she turned very accurately in the direction of the nest entrance. At the nest entrance there were five workers who also started to buzz when the Ps. approached. After a few seconds the whole nest seemed to be alarmed and all the workers started to walk very quickly over the nest. They were buzzing and started fighting. Some ten workers attacked the Ps. and "balled" her while trying to sting her (fig. 1). Other workers actually stung each other. The $B$. terrestris queen remained relatively quiet and stayed on the nest and only buzzed occasionally. After ten minutes the workers started to attack their own queen too, and this made her leave the comb. The fights between the Ps. and the workers continued for 30 minutes and, at the end, 31 workers were dead. The Ps. rested on the nest for several minutes and tried in vain to remove the head of a worker from her left anterior wing. After a short pause she started wandering over the nest. Upon meeting a worker, the Ps. grasped her tightly for several seconds. The Ps. extended her sting but did not make any effort to sting the worker (fig. 2). Instead, she went on to another worker and repeated this behaviour. Each of the workers was treated once or twice in this way. An exception was made for the queen. The queen had returned to the 


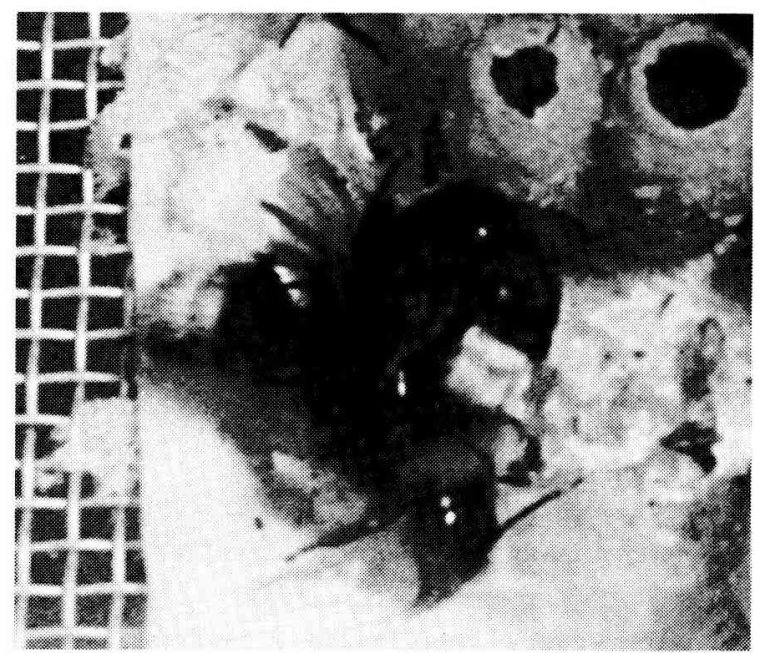

FIG. 1. - After she has entered the nestbox, the Psithyrus is attacked vigorously by workers trying to sting her.

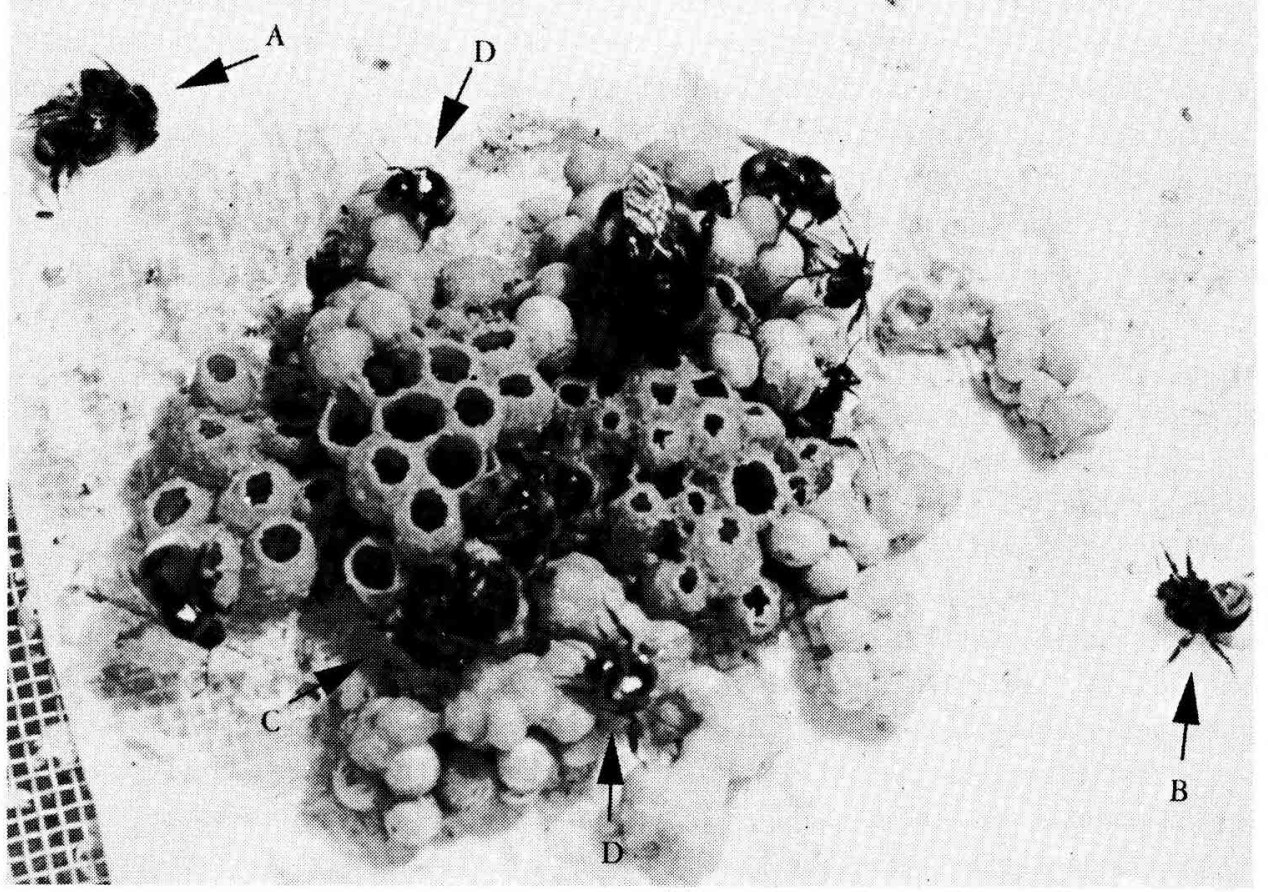

FIG. 2. - The Psithyrus has succeeded in establishing herself in the Bombus colony.

A worker can be seen stinging one of her sisters (A);

another worker has taken the defense attitude (B).

The Psithyrus is holding one of the workers in a tight grip (C).

Several others workers are buzzing (D). 
comb and remained very passive. She would leave the comb now and again. The $P s$. showed no agonistic behaviour towards the queen at this stage. Four hours after the introduction of the Ps., the nest appeared to be quite peaceful (fig. 3). On the 5 th of June, four days after the introduction, the Ps. started to push the queen off the comb. The queen made no real effort to defend herself, and only lifted a leg. She became very passive and we did not see her eat. On the 6 th of June the Ps. succeeded in chasing the queen off the nest. The queen gradually began to move more and more slowly; at the end of the day she died. We never saw the Ps. try to sting the queen or vice versa.

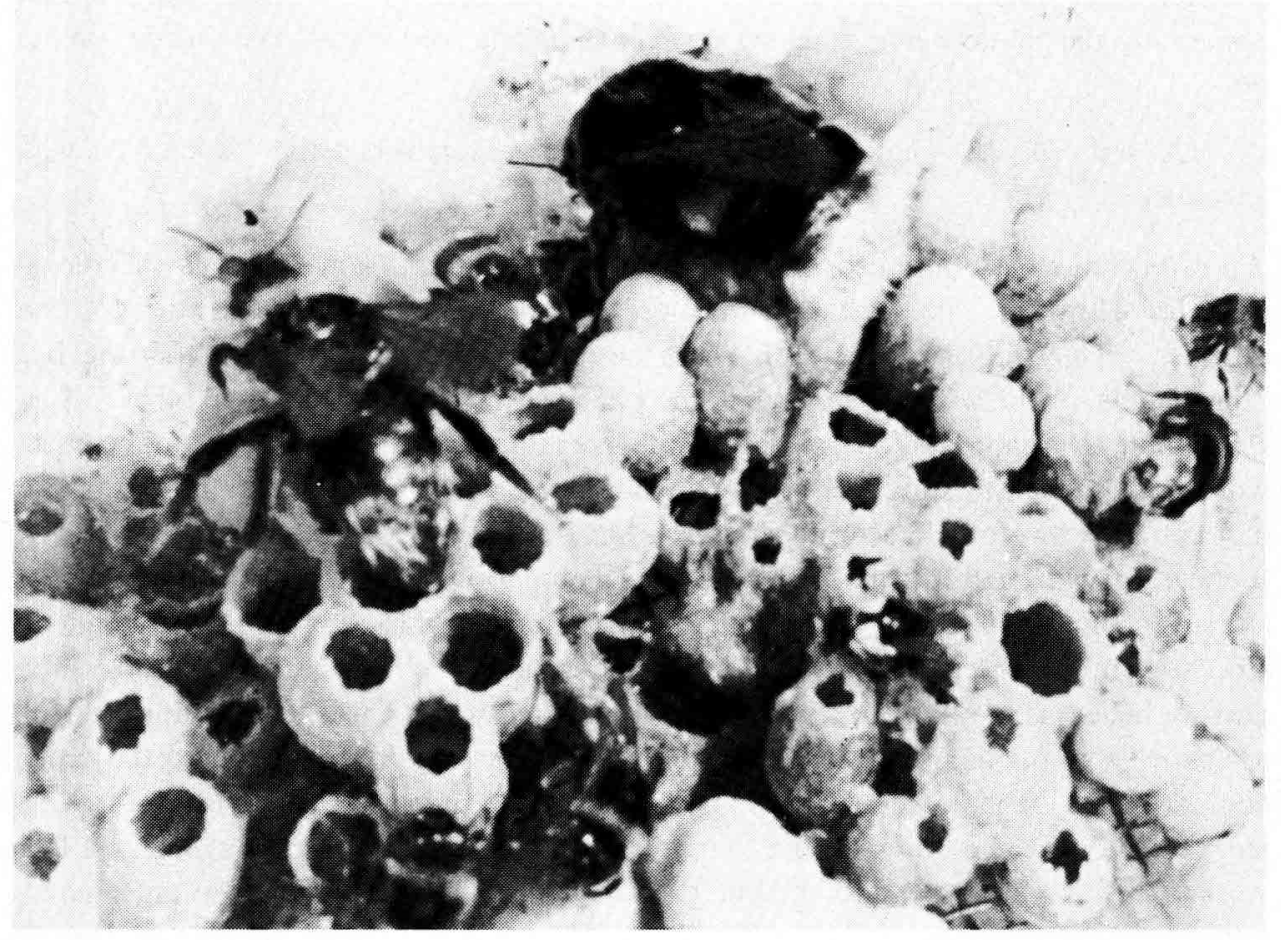

FIG. 3. - After the fights end the Bombus queen and the Psithyrus are on the same comb without apparent signs of animosity.

The Ps. started to lay eggs on the 12th of June, 11 days after her introduction into the nest, and the workers started to lay eggs at about the same time. The Ps. chased the laying workers off their brood with great ferocity, and 11 workers were killed in these encounters. The Ps. ate the eggs and destroyed the young larvae of the workers, but based on the emergence of males, we conclude that she was not able to destroy all of the workers' progeny. 
The workers started to interfere with the activities of the $P s$. on the 20th by approaching the $P s$. and buzzing frequently. The $P s$. avoided confrontation by walking away. On the 21 st she was ignored, but on the 22 nd the workers became ferocious. They succeeded in forcing the Ps. off the nest. The workers also started to destroy parts of the brood of the Ps. Only eggs and young larvae were destroyed; older larvae and pupae were not touched. The agonistic behaviour of the workers towards the Ps. continued until the 29th. She was always surrounded by several workers, who buzzed near her head and eventually started to pull her legs and wings. She left the comb on the 29 th, and died the next day. The progeny of the Ps. numbered 6 males and 3 females which all emerged on the 11 th of July. The $B$. workers who emerged on the 22 nd and 23 rd of June were exceptionally small; apparently the larvae were not fed or were inadequately fed after the introduction of the Ps.

Colony No. 2. This colony contained 27 workers when the Ps. vestalis was introduced.

The Ps. was introduced on June 5th, in exactly the same way as in colony No. 6. However the workers in this colony were more agonistic to the intruder. They followed her trail in the outer compartment and tried to sting her immediately. The workers also ran about buzzing and tried to sting each other. The Ps., unable to escape from the workers who were attacking her, stung them. The other workers continued to sting the already dead workers whenever they found them. The nest entrance was found accurately as the other Ps. had done in colony No. 6. One of the workers who had met the Ps. in the outer compartment alerted the colony and she started to run and buzz very emphatically upon her return to the nest. The $B$. queen left the comb in the general excitement which ensued. When the Ps. arrived on the nest we believe that she merely tried to avoid contact with the workers by hiding under a "bunch " of pupae. Eventually the Ps. left the nest again and fled into the outer compartment. The workers on the comb gradually quieted down. Most of them stopped buzzing and running and started to take care of the brood again. A few workers followed the Ps. into the outer compartment. The fights in the outer compartment started once again, but after several vain attempts to sting the $P$ s. these workèrs aiso became somewhat calmer. One hour later the $P$ s. returned to the nest but she was repeatedly chased away by the queen. This went on for a whole day but on June 8th the situation changed completely : the Ps. was ignored by the queen and workers. The Ps. started to push the queen around and started to grab the workers on the comb, making stinging movements towards them, as the other Ps. had done in nest No. 6. The $B$. queen finally died on June 9th. From June 12 th onwards, the workers started to interfere with the activities of the intruder who had started to lay eggs, and several workers began to try to destroy her batches of eggs. The workers took up a position at the head of the Ps., buzzing frequently in this head-to-head position. A climax was reached on June 15 th when 20 workers were killed in violent fights with the 
Ps. On this day the workers also started to lay eggs. The Ps. was very active in destroying the workers' eggs. However the workers were never seen destroying the brood of the Ps. The Ps. was chased off the nest on the 11th of July. Her progeny numbered 26 males and 57 females.

Data relating to the development of the colonies are shown in Table 1. From this table we calculated data for several parameters to be used for further analysis. These are shown in Table 2. Table 3 shows the composition of the colonies after the fights between the intruder and the workers.

\section{DISCUSSION}

A Ps. vestalis female was introduced into two colonies of $B$. terrestris, containing 40 and 27 workers respectively. Although the first of these nests was fairly well developed compared to the nests on which SLADEN made his observations, we are inclined to think that it was roughly the size of natural colonies when they were parasitized. The $P$ s. who left their hibernacula at the end of May, are unlikely to have found much smaller $B$. colonies in the Utrecht area.

Il we compare the nest sizes at the time of introduction with the data on the sizes of nests in which workers started to lay eggs under normal conditions (VAN HoNK et al., 1980), we can conclude that the colonies used in the experiment were headed by queens who were still fully dominant. The workers in colonies with a dominant queen do not start to lay eggs until there are approximately 80 workers in the nest. Consequently, the $P s$. females took over colonies in which the workers were still fully dominated and not yet " ready " for laying eggs.

From Table 2 it is easy to calculate that in colonies 6 and 2, only 9 and 5 workers respectively survived the introduction of the $P$ s. Table 3 A shows the age distribution of surviving workers. Only the young workers were not killed. After taking over the colony, the $P S$. was in the company of a few young workers, the brood of the $B$. queen and the $B$. queen. The oldest workers not killed during the introduction of the Ps. were 8 days old. At this age, workers in $B$. colonies are not ready for oviposition. We calculated an average age of 40 days for workers who started to lay eggs in colonies headed by a queen who had not been deprived of her mandibular glands (VAN HONK et al., 1980).

At the time of the first worker-oviposition, the colonies contained 53 and 46 workers respectively. The worker ages at that moment are shown in Table $3 \mathrm{~B}$. The workers who were 0 - and 1-day old were very passive on the nest. These workers cannot be regarded as having played an important role in surpassing the " threshold " of worker oviposition. If we do not count these workers, colonies No. 6 and No. 2 contained 35 and 21 workers respectively. The ages of the oldest workers were 20 and 18 days respectively. Compared with the sizes of nests and ages of workers in $B$. 
C. VAN HONK, P.-F. RÖSELER, H. VELTHUIS and M. MALOTAUX

TABL. 1. - Life tables for the populations of colonies No. 6 and 2.

\begin{tabular}{|c|c|c|c|c|c|c|c|c|c|c|}
\hline \multirow{3}{*}{ Date } & \multicolumn{5}{|c|}{ Colony No. 6} & \multicolumn{5}{|c|}{ Colony No. 2} \\
\hline & \multicolumn{3}{|c|}{ Bombus } & \multicolumn{2}{|c|}{ Psithyrus } & \multicolumn{3}{|c|}{ Bombus } & \multicolumn{2}{|c|}{ Psithyrus } \\
\hline & emer & ged & killed & emerged & killed & emer & rged & killed & emerged & killed \\
\hline $\begin{array}{r}8-5 \\
10-5 \\
11-5 \\
16-5 \\
21-5 \\
23-5 \\
24-5 \\
25-5 \\
26-5 \\
29-5 \\
30-5 \\
31-5 \\
1-6 \\
5-6 \\
6-6 \\
7-6 \\
8-6 \\
9-6 \\
12-6 \\
136 \\
15-6 \\
17-6 \\
19-6 \\
20-6 \\
22-6 \\
23-6 \\
26-6 \\
27-6 \\
29-6 \\
30-6 \\
1-7 \\
3-7 \\
11-7 \\
14-7 \\
17-7 \\
19-7 \\
20-7 \\
24-7 \\
25-7 \\
27-7 \\
28-7 \\
31-7 \\
1-8\end{array}$ & $\begin{array}{r}4 \varnothing \\
1 \\
3 \\
\\
15 \\
2 \\
\\
5 \\
4 \\
5 \\
1 \\
\\
13 \\
3 \\
9 \\
2 \\
1 \\
18 \\
14 \\
1 \\
\\
13 \\
10 \\
5 \\
1 \\
10 \\
\end{array}$ & $\begin{array}{l}10^{\circ} \\
100^{\star} \\
4 \sigma^{\circ} \\
15 \sigma^{\star} \\
19 \sigma^{\star} \\
6 \sigma^{\star}\end{array}$ & $\begin{array}{r}31 \gamma \\
\quad \\
\\
2 \\
3 \\
2 \\
3 \\
1\end{array}$ & $3 q 6 d^{3}$ & q & $\begin{array}{r}1 \zeta \\
2 \\
2 \\
1 \\
2 \\
1 \\
4 \\
6 \\
8 \\
\\
\\
8 \\
8 \\
\\
\\
25 \\
22 \\
\\
16 \\
14 \\
7 \\
8 \\
25 \\
4 \\
45 \\
4 \\
4\end{array}$ & $\begin{array}{l}10 \\
40^{x}\end{array}$ & $\begin{array}{c}22 \gamma \\
q \\
20 \nvdash\end{array}$ & 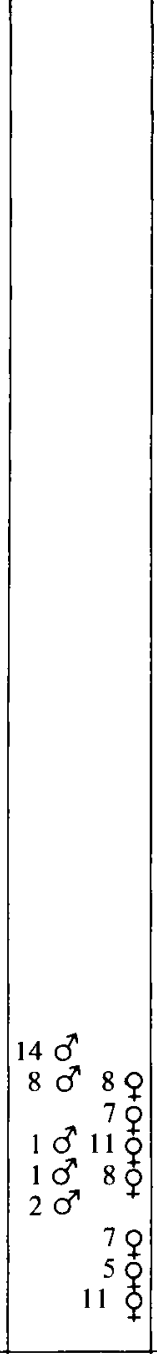 & 우 \\
\hline Totals & $150 \varnothing$ & $550^{\circ}$ & $42 \zeta 1 q$ & $30 \quad 60^{\circ}$ & $1 q$ & $217 \varnothing$ & $50^{7}$ & $48 \varnothing 1 q$ & $260^{7} 57$ ठ & $1 \delta$ \\
\hline
\end{tabular}

colonies headed by queens who have been deprived of their mandibular glands ( 21.5 workers and 23.5 days), we see that the data for laying workers in parasitized colonies are in perfect agreement with the data for colonies headed by a queen without 
TABL. 2. - The effect of the introduction of a Psithyrus vestalis on the development of the colonies of its host species Bombus terrestris calculated from the data in Table 1.

\begin{tabular}{|c|c|c|}
\hline & \multicolumn{2}{|c|}{ Colony Nos. } \\
\hline & 6 & 2 \\
\hline Number of workers at the time of Ps. introduction $\ldots$ & 40 & 27 \\
\hline Number of workers killed during introduction $\ldots \ldots \ldots$ & 31 & 22 \\
\hline Total number of workers killed by $P$ s. . . . . . & 42 & 48 \\
\hline Number of workers when $P s$. lays first egg . . . . . . & 50 & 21 \\
\hline Maximum number of workers during presence of $P s . \ldots \ldots$ & 98 & 161 \\
\hline Total number of workers emerged in the nest $\ldots \ldots \ldots \ldots \ldots$ & 150 & 217 \\
\hline Number of $B$. males emerged in the nest $\ldots \ldots \ldots \ldots$ & 55 & 5 \\
\hline Males that are offspring of workers $\ldots \ldots \ldots \ldots \ldots \ldots \ldots \ldots \ldots \ldots$ & 54 & 4 \\
\hline Number of workers at first worker-oviposition $\ldots \ldots \ldots \ldots$ & 53 & 46 \\
\hline
\end{tabular}

TABL. 3. - The ages and numbers of workers in the colonies

A : At the end of the fights with the intruding Psithyrus.

B : At the moment of the first worker-ovipositions.

$\mathrm{C}:$ At the moment the first workers start to lay eggs and the fights with the Psithyrus have ended.

\begin{tabular}{|c|c|c|c|c|c|c|}
\hline & \multicolumn{2}{|c|}{$A$} & \multicolumn{2}{|c|}{$B$} & \multicolumn{2}{|c|}{$C$} \\
\hline & $\begin{array}{l}\text { number } \\
\text { workers }\end{array}$ & $\begin{array}{c}\text { age in } \\
\text { days }\end{array}$ & $\begin{array}{c}\text { number of } \\
\text { workers }\end{array}$ & $\begin{array}{l}\text { age in } \\
\text { days }\end{array}$ & $\begin{array}{c}\text { number of } \\
\text { workers }\end{array}$ & $\begin{array}{l}\text { age in } \\
\text { days }\end{array}$ \\
\hline Colony No. 6 & $\begin{array}{l}4 \\
4 \\
1\end{array}$ & $\begin{array}{l}8 \\
3 \\
1\end{array}$ & $\begin{array}{r}4 \\
4 \\
1 \\
11 \\
3 \\
9 \\
2 \\
1 \\
18\end{array}$ & $\begin{array}{r}20 \\
15 \\
13 \\
7 \\
6 \\
5 \\
4 \\
3 \\
0\end{array}$ & $\begin{array}{r}4 \\
4 \\
11 \\
3 \\
9 \\
2 \\
1 \\
13\end{array}$ & $\begin{array}{r}20 \\
15 \\
7 \\
6 \\
5 \\
4 \\
3 \\
0\end{array}$ \\
\hline Colony No. 2 & $\begin{array}{l}\text { after ir } \\
5 \\
\text { after se } \\
2 \\
13 \\
11\end{array}$ & $\begin{array}{r}\text { detion } \\
8 \\
\text { fights } \\
18 \\
7 \\
1\end{array}$ & $\begin{array}{r}5 \\
16 \\
25\end{array}$ & $\begin{array}{r}18 \\
7 \\
1\end{array}$ & $\begin{array}{r}2 \\
13 \\
11\end{array}$ & $\begin{array}{r}18 \\
7 \\
1\end{array}$ \\
\hline
\end{tabular}

mandibular glands (VAN HoNK et al., 1980 a). Apparently the $B$. female is just as potent in inhibiting worker oogenesis as a $B$. queen without mandibular glands. Therefore it is very unlikely that the $P s$. female produces pheromones that inhibit oogenesis in workers.

From Table $3 \mathrm{C}$ it becomes evident that the Ps. in colony No. 6 had to cope with a group of workers that differed greatly in size and age composition from the group of 
workers that was left in colony No. 2 after the workers had started to lay eggs and the killing had ceased. Males take about 25 days to develop under the conditions in which we keep our colonies. This means that colony No. 6 had a larger population than colony No. 2 when the workers laid the bulk of their eggs (table 1). The Ps. female in colony No. 6 had to cope with more workers and also with more workers who, due to their age, were laying eggs, than the Ps. in colony No. 2. Consequently colony No. 6 yielded more males than colony No. 2 and the reproductive success of the Ps. in colony No. 6 was much less than the Ps. in colony No. 2.

In both cases the $P$ s. found the nest entrance very accurately once they had arrived at the honey reservoir. Apparently Ps. Vestalis is able to follow the trail of $B$. terrestris workers into the nest, just as Ps. rupestris is able to follow the trail of $B$. lapidarius workers (CEDERBERG, 1977, 1979).

Once the $P$ s. entered the nest, the workers not only attacked the intruder but also started stinging each other. The speed with which this aggression spreads through the colony makes it tempting to suppose that there is some kind of communication regarding the intrusion. This might be the alarm pheromone (Maschwitz, 1964). We estimate that at least $30 \%$ of the bees that were killed during the intrusion were actually killed by their sisters. The workers repeatedly tried to sting workers who had already been stung by their sisters or the Ps. They were attracted to those workers in a way that is very reminiscent of the way in which workers of the honeybee are attracted to the secretion from the poison gland which marks a victim after it has been stung.

As far as the behaviour of the Ps. towards the $B$. queen is concerned, we can fully confirm the observations of SLADEN that the Ps. does not attack the queen until several days have passed. After several encounters in which the intruder succeeded in pushing the queen off the nest, the latter left the nest. We never saw the $P s$. attempt to kill the queen. This is very similar to the situation in B. terrestris colonies towards the end of colony development. In these nests, the queen is almost always pushed off the nest by workers who are laying or about to start laying, rarely is she stung by her workers. The behaviour of these workers prior to the expulsion of the queen is very similar to the behaviour of the Ps. (VAN HoNK et al., submitted). In declining colonies, a number of workers follow the queen over the nest, occasionally buzzing at her head. This starts when the first few groups of workers have emerged, and it reaches a climax after the first workers have started to lay eggs. These " buzzers " are the first workers to lay eggs. Eventually the agonistic character of the interactions between queen and workers is displayed more openly and the interactions become more frequent. The whole process resembles a "de-ritualization " process. The workers start to pull the queen's legs and finally she either stops interfering with the laying activities of the workers or she leaves the nest. The Ps. also started buzzing towards the queen and gradually became more aggressive and finally forced the queen off the nest. 
There is another parallel in the behaviour of the Ps. and the bumblebee queen which has not yet been considered. Shortly after the $P S$. had taken up her position on the nest, which may be directly after entering the nest (colony No. 6) or a day later (colony $\mathrm{N}^{\circ} 2$ ), she took each of the workers in a tight grip and showed her sting. This was a very efficient way of calming the workers down, because for a few days they stopped bothering her. The $B$. terrestris queen who is losing her dominant position in her colony also makes vigorous assaults on her workers, but without showing her sting. This behaviour is shown infrequently as long as the first worker is trying to lay eggs, but it becomes more frequent when several workers start laying eggs. The queen repeats this type of behaviour much more often than the Ps. did in the two colonies discussed here. Although the interactions of the Ps. with workers who start to lay eggs are less numerous than between queen and workers, they are much more ferocious. Many workers are killed in the fights which result from the $P_{s}$. interfering with the laying activities of the workers.

Received for publication in November 1980.

\section{RÉSUMÉ}

LA CONQUETTE D'UNE COLONIE DE BOURDONS PAR UNE FEMELLE DE PSITHYRE

Deux femelles de psithyre, Psithyrus vestalis, ont été capturées au printemps et introduites dans deux colonies de bourdons de l'espèce Bombus terrestris, qui avaient été élevées en captivité. L'une des colonies comportait 40 ouvrières, l'autre 27 . Le comportement a été enregistré à l'aide d'une caméra à cassettes vidéo, puis analysé.

Les psithyres trouvèrent l'entrée des nids de bourdons en suivant la piste odorante des butineuses. Dès ce moment les psithyres furent vigoureusement attaqués par les ouvrières. La pénétration des psithyres dans les nids provoqua une grande excitation dans les colonies. Non seulement les ouvrières se précipitèrent sur les psithyres, mais elles se battirent aussi mutuellement et attaquèrent même leur reine. Ceci entraîna la mort de nombreuses ouvrières. Lorsque les femelles de psithyres eurent occupé les nids, les ouvrières restantes se calmèrent. A cette phase-là les femelles de psithyres montrèrent un comportement particulier : elles étreignirent les ouvrières en sortant leur aiguillon sans pourtant les piquer. Quelques jours plus tard elles chassèrent du rayon la reine Bombus.

Les psithyres se trouvèrent aussi dans la situation d'empêcher la formation d'œufs chez les ouvrières de Bombus. L'action inhibitrice fut néanmoins plus faible que celle des reines intactes de bourdon et correspondit environ à celles de reines dont les glandes mandibulaires ont été extirpées. C'est pourquoi au bout d'environ 3 semaines les ouvrières commencèrent à pondre. Elles entrèrent alors en concurrence avec les psithyres, elles se comportèrent de façon agressive entre elles et détruisirent leurs œufs et les jeunes larves. C'est pourquoi le nombre de descendants d'une femelle de psithyre semble dépendre du début de la ponte des ouvrières de bourdons, i.e. de l'âge des ouvrières qui ont survécu à leurs attaques lors de l'occupation du nid. 


\section{ZUSAMMENFASSUNG}

\section{DIE ERWERBUNG EINER KOLONIE VON BOMBUS TERRESTRIS DURCH EIN WEIBCHEN DER ART PSITHYRUS VESTALIS}

Zwei Weibchen der Schmarotzerhummel Psithyrus vestalis wurden im Frühjahr gefangen und in Hummelvölker der Art Bombus terrestris eingeführt, die in Gefangenschaft gezüchtet worden waren. Das eine Volk besass 40 , das andere 27 Arbeiterinnen. Das Verhalten wurde mit Hilfe einer Videokamera registriert und anschliessend ausgewertet.

Die Schmarotzerhummeln fanden den Eingang zu den Hummelnestern, indem sie der Duftspur der Sammlerinnen folgten. Bereits dabei wurden sie von den Arbeiterinnen heftig attackiert. Das Eindringen der Schmarotzerhummeln in die Nester versetzte die Völker in grosse Aufregung. Die Arbeiterinnen stürzten sich aber nicht nur auf die Schmarotzerhummeln, sondern attackierten sich auch gegenseitig und sogar ihre eigene Königin. Dabei wurden viele Arbeiterinnen getötet. Nachdem die Psithyrus-Weibchen die Nester okkupiert hatten, beruhigten sich die verbliebenen Arbeiterinnen. In dieser Phase zeigten die Psithyrus-Weibchen ein eigenartiges Verhalten : Sie umklammerten die Bombus-Arbeiterinnen, wobei sie den Stachel ausreckten, ohne jedoch die Arbeiterinnen zu stechen. Nach einigen Tagen vertrieben sie die Bombus-Königin von der Wabe.

Die Schmarotzerhummeln waren ebenfalls in der Lage, die Eibildung den Bombus-Arbeiterinnen zu hemmen. Die Hemmwirkung war jedoch schwächer als die von intakten Bombus-Königinnen und entsprach etwa derjenigen von Königinnen, deren Mandibeldrüsen operativ entfernt worden waren. Nach etwa 3 Wochen begannen deshalb auch die Arbeiterinnen, Eier zu legen. Damit gerieten sie in Konkurrenz zu den Schmarotzerhummeln, sie verhielten sich ihnen gegenüber agonistisch und zerstörten ihre Eier und jungen Larven. Die Zahl der Nachkommen eines Psithyrus-Weibchens scheint deshalb vom Beginn der Eiablage der Bombus-Arbeiterinnen abzuhängen, d.h. vom Alter der Bombus-Arbeiterinnen, die ihre Angriffe bei der Okkupation des Nestes überlebt haben.

\section{REFERENCES}

Cederberg B., 1977. - Evidence for trail marking in Bombus terrestris workers. Zoon 5 : 143-146.

Cederberg B.; 1979. - Dofstyrt värdval hos snylthumlor. Ent. Tidskr. 100, 128-129.

FREE J. B., 1961. - The social organization of the bumble-bee colony. North Hants. Printing and Publish ing Co., Fleet.

Free J. B. and Butler C. G., 1959. - Bumble-bees. Collins, London.

HoFFER Ed., 1889. - Die Schmarotzerhummeln Steiermarks. Graz.

KiRBY W., 1802. - Monographia Apum Angliae. Raw, Ipswich.

MASCHWITZ U., 1964. - Gefahrenalarmstoffe und Gefahrenalarmierung bei sozialen. - Hymenopteren. $Z$. vergl. Physiol. 47, 596-655.

Michener C. D., 1974. - The social behaviour of the bees. Belknap Press, Cambridge, Mass.

PlatH O. E., 1934. - Bumble-bees and their ways. MacMillan and Co., New York.

SACHS L., 1978. - Angewandte Statistik. Springer, Berlin-Heidelberg-New York.

SLADEN F. W. L., 1912. - The humble-bee, its life-history and how to domesticate it. MacMillan an Co., London.

Van Honk C. G. H., Velthuis H. H. W., Röseler P.-F. and Malotaux M. E., 1980 a. - The mandibular glands of Bombus terrestris queens as a source of queen pheromones (submitted).

Van Honk C. G. H., Röseler P.-F., Velthuis H. H. W. and Hoogeveen J. - Factors influencing egg-laying activities of workers in a captive Bombus terrestris colony and possible consequences for the transmission of genes by both castes (submitted). 